\title{
NEGATIVE IMPACTS OF FORCED MARRIAGE IN AISHA SAEED'S NOVEL WRITTEN IN THE STARS
}

\author{
Kahfiatika, M. Manugeren \\ Universitas Islam Sumatera Utara, Medan, Indonesia \\ e-mail:kahfiatika97@gmail.com
}

\begin{abstract}
Written in the Stars is a novel, written by Aisha Saeed. Written in the Stars was originally published in 2000 but republished again March 24th 2015. The story is about a Pakistani-American high school senior girl, torn between love for her culturally conservative immigrant parents and the boyfriend she keeps secret from them. When her outraged parents discover the romance, they take her and her brother on a vacation to visit relatives in rural Pakistan, with plans to force her into an arranged marriage to a local man. The objectives of this study are to find out the negative impacts of forced marriage in Aisha Saeed's novel Written in the Stars and to describe the negative impacts of forced marriage. Qualitative Descriptive Research is appropriately applied in this study because this research shows the nature of the situation as it exists at the time of the study. The results of this study show that the implementation of Forced marriage only brings negative impacts to one or both parties. There are two forms of negative impacts found: violence and loss of social relationship. Violence is again divided into two forms: physical violence and verbal abuse.
\end{abstract}

Keywords: Forced Marriage, Physical Violence, Social Relationship, Verbal Abuse.

\section{Introduction}

Written in the Stars is a 289 page novel, written by Aisha Saeed, originally published in 2000 but republished again March 24th 2015 and listed as a best book of 2015 by Bank Street Books and a 2016 YALSA Quick Pick for Reluctant Readers.

The story goes to a Pakistani-American high school senior girl, torn between love for her culturally conservative immigrant parents and the boyfriend she keeps secret from them. When her outraged parents discover the romance, they take her and her brother on a "vacation" to visit relatives in rural Pakistan, with plans to force her into an arranged marriage to a local man.

The novel talks of the issue of forced marriage in line with the local tradition of the characters in the novel. The definition of force includes physical, psychological, sexual, financial and emotional pressure as well as emotional and psychological abuse or harassment and there are many things that people in many different countries are doing to help prevent forced marriages so that it is important to tell the society that forced marriage is a serious problem right and is not appropriate anymore to the current situations as forced marriage produces various social problems. A way to spread the issues of the negative impacts could be done through academic research and this writing, a thesis, also plays an important role to socialize the matters caused by forced marriage. There are two points of discussion in this writing: violence and the loss of social 
Negative Impacts of Forced Marriage in Aisha Saeed's Novel Written In The Stars, Kahfiatika, M. Manugeren

relationship. Violence is again sub-divided into two forms: physical violence and verbal violence.

\section{Literature Review \\ 2.1 Marriage}

In modern times, the important aspects of marriage are social, religious as well as legality. Marriage differs, of course, from other sex relations by the fact that it is a legal institution. It is also in most communities a religious institution, but it is the legal aspect which is essential" (Kefalas, 2011).

From this point of view, marriage is not merely a sexual relationship, but a parental association. It is the union of a male and a female for production and care of offspring and reproduction, therefore, this is another fundamental object or purpose of marriage. Marriage as a physical as well as a moral union is recognized by society as the basis of a family.

\subsection{Forced Marriage}

A forced marriage occurs when people are coerced into a marriage against their will and under duress, which can include both physical and emotional pressure. A forced marriage is very different from an arranged marriage in which the free and informed consent of both parties is present. The most common type of forced marriage occurs when parents or other family members force one or both of the participants into the marriage. This type of forced marriage is usually supported by the surrounding community, making it difficult to avoid or escape (Bredal, 2011).

Forced marriage is overwhelmingly a form of power and control used against women and girls. Like partner abuse, rape and other forms of sexual assault, it is used to control women, their sexuality, and often, their offspring. If forced marriage is not positioned as a form of violence against women, women's treatment and status throughout society will not be examined, leaving the roots of this form of violence, women's inequality, untouched.

The definition of force includes physical, psychological, sexual, financial and emotional pressure as well as emotional and psychological abuse or harassment. Forced marriage involves situations where you feel pressured to the point where you agree, but only because you feel you did not have the choice to say no, and you would not have consented had the pressure not been placed on you (Millbank, 2011).

\subsection{Impact of Forced Marriage}

Forced marriage can be seen as an abuse of human rights, a form of domestic abuse and a form of violence against the person, both male and female. When it involves people with a disability or severe mental illness it is an abuse against a vulnerable adult. If it affects children and young people, it is child abuse; so it is worth noting the manner in which issues such as child forced marriage are represented as harmful cultural practice while instance of everyday violence against women, particularly in majority communities, such as domestic violence and marital rape always exists.

Forced marriage as already mentioned above, is a violence against human rights and it is a crime towards humanity with various forms of impacts. The significant ones always seen are violence in the forms of physical violence, emotional violence, and Verbal Violence. Loss of contact with the surrounding is another form of the impact of forced marriage (Sabbe. et al., 2014). 


\subsection{Violence}

Violence is one of the most problematic issues society faces today, and it has been increasing day after day, in the streets of our cities. The most common description of what violence really is can be given as negativity towards something or someone either through physical or verbal actions, which often causes the victim to suffer pain. The different types of violence that exist in our multi-cultural society are out-numbered, but the most evident ones are domestic, gang, sexual, and racial violence. While violence can definitely be reduced, it will never be eliminated due to the nature of humans (Flannery, 2015).

As with its impacts, some causes of violence are easy to see. Others are deeply rooted in the social, cultural and economic fabric of human life. Recent research suggests that while biological and other individual factors explain some of the predisposition to aggression, more often these factors interact with family, community, cultural and otherexternal factors to create a situation where violence is likely to occur.

\subsubsection{Physical Violence}

Depending on the breadth of definition, violence is a ubiquitous social phenomenon. Alongside state and collective violence, such as dictatorship, state terrorism and situations of civil war or war, individual violence in the public or in the private domain is in the focus of interest with regard to the everyday situation. Violence constitutes a serious form of aggression, entailing, in addition to malice, also an imbalance in psychological or physical power. Frequently, research distinguishes between direct (physical) and indirect forms of violence (verbal/psychological and social/relational, i.e. with the intention of damaging social relationships). With regard to individual violence, a further differentiation can be made according to the various social environments, within which an act of violence may occur: domestic violence, i.e. violence by or against a partner or another family member, violence in the workplace, or violence between known or previously unknown persons (Schlack, 2013: 1 - 3). Physical violence occurs when someone uses a part of their body or an object to control a person's actions.

\subsubsection{Verbal Abuse}

Verbal abuse is a common variety of violence, which encompasses a relatively large spectrum of behaviors, including accusing, undermining, verbal threatening, ordering, trivializing, constant forgetting, silencing, blaming, name-calling, overtly criticizing. Verbal abuse is compatible with other forms of violence, including physical violence and psychological violence. Verbal abuse can also be categorized as hate speech, words expressed to cause hurt others. Hate speech can be understood as any form of expression that is propagated to incite, promote or justify racial hatred, xenophobia, anti-Semitism, or other forms of hatred rooted in intolerance, including intolerance expressed by nationalism and aggressive ethnocentrism, discrimination and hostility towards minorities and migrants (Weber in Rangkuti, et.al., 2019).

Verbal abuse may be sometimes seen also a form of liberation for the most oppressed. The exercise of humor may be in some case entrenched with some forms of verbal abuse: from politically incorrect jokes to simple mocking, humor may seem a manner to exercise violence over other people. At the same time, humor is amongst the most democratic and gentle tools for social protests, as it requires no particular affluence and arguably provokes no physical damage and need not cause great psychological distress. The exercise of verbal abuse, perhaps more than any other forms of violence, 
Negative Impacts of Forced Marriage in Aisha Saeed's Novel Written In The Stars, Kahfiatika, M. Manugeren

requires a continuous check on the part of the speaker of the reactions to her words: humans almost invariably end up exercising violence over each other; it is only by educating people to try and refrain from their behaviors that they may be able to live peacefully (Holly, 2016).

\subsection{Loss of Social Relationship}

Loneliness is linked to an increased risk of heart disease, viral infections, cancer and Changes in the immune system. They assure that a person's social environment can affect their health, with those who are socially isolated are exposing to a high risk of mortality than people who are not. This shows that social relationship is important without which no one could survive in life (Psaltis, 2015).

It is already known that a person's social environment can affect their health, with those who are socially isolated-that is, lonely suffering from higher mortality than people who are not. Feelings of social isolation are linked to alterations in the activity of genes that drive inflammation, the first response of the immune system. Having previously established that lonely people suffer from higher mortality than people who are not, researchers are now trying to determine whether that risk is a result of reduced social resources, such as physical or economic assistance, or from the biological impact of social isolation on the function of the human body, and the loss of social relationship might cause one to live a life of terror and threat (Holt-Lunstad, 2018).

\section{Research Method}

Qualitative research is implemented in this study. The main data are taken from the novel in the forms clauses, sentence referring to negative impacts of forced marriage and then interpreted into the form of words rather than numbers (Creswell: 2013). Following Herbert's theory (1993: 43) that a library research is a research to collect ideas, theories, and reported empirical data within the context of scholarship in the library, the supporting data for this study are then collected from many sources, especially books and websites.

The analysis focuses on physical violence, verbal abuse and loss of friendship or environment. The mass of data have to be organized and somehow meaningfully reduced or reconfigured. The data reduction refers to the process of selecting, focusing, simplifying, abstracting, and transforming the data that appear in written up field notes or transcriptions. Not only do the data need to be condensed for the sake manageability but also also have to be transformed so they can be made intelligent in terms of the issues being addressed.

\section{Discussion}

\subsection{Physical Violence}

Both male and female victims may be subject to repeated sexual assault (including rape), domestic violence from their partner or extended family, or enforced domestic family service. Women may be disproportionately affected by sexual assaults.

Violence often occurs in forced marriages because of a sense of control. When a girl marries a man from a rich family, feeling of control everything gets bigger. In the end, they use the road of physical violence to remind her daughters-in-laws with whom they marry and how they should behave and what will happen if they fight against their in-laws. The following quotation proves physical violence that happens in the novel: 
"You will keep doing these dishes until they are perfect, and you will keep doing them again and again for the rest of your life until you learn how to do it right." (Saeed, 2000: 170).

The quotation above shows how Naila's mother-in-law, Nasim, gives Naila a lot of hard works to bestow Nasim's resentment at Naila for not behaving the way Nasim wants her to. It can be seen Nasim's action is to intimidate Naila. Nasim tries to tell Naila that in this house Nasim is in charge, and Naila will keep receiving physical violence like this as long as Nasim does not get what her wish.

Other evidence is seen when Amin, Naila's husband, uses forces on Naila when he wants to have sex with her. This matter shows that instead of getting happiness, Naila feels that she is being tortured as indicated in the quotation below:

I try to sit up, to reach for the light on the nightstand, but his hands press against my shoulders, pushing me down.

arms are pinned behind me. My body is racked with sobs as he pulls at my clothing. Suddenly, I scream. Pain envelops me.

feel numb (Saeed, 2000: 186).

The quotation above indicates that Naila's husband, Amin, forces Naila to have sex. When Naila states her refusal and beg Amin not to do it, Amin continues to do so by using physical force against Naila. When Naila tries to sit up to reach the light, Amin with his hand presses against Naila's shoulders to stop her from doing so. Amin pins Naila's arms to stop her fight against what he does. Naila feels hurt and finally Naila becomes numb. She cannot feel any pain anymore. Having sex for Naila is more like getting raped.

\subsection{Verbal Abuse}

Verbal abuse may be sometimes seen from a form of liberation for the most oppressed. Humor may be in some case entrenched with some forms of verbal abuse: from politically incorrect jokes to simple mocking, humor may seem a manner to exercise violence over other people.

Verbal abuse often occurs in order to isolate someone, usually it discourages someone and eliminates one's confidence. In the novel, verbal abuse often occurs when Nasim, Naila's mother-in-law, and Saba, Naila's sister-in-law, are not satisfied with Naila's behavior. Nasim and Saba continue to give sarcastic comments to Naila in the hope that Naila would be aware of her position:

My sister is coming in a few hours," Nasim says over lunch the next day.

"Can you put something decent on before she arrives? There are atleast ten outfits pressed and hanging in your closet. It shouldn't be too difficult to pick one." (Saeed, 2000: 165).

Nasim gives sarcastic comments to Naila. Nasim is offended because Naila is wearing clothes from her parents' house, instead of clothes given by Nasim's family. Nasim feels Naila does not respect her family. Therefore, Nasim says to Naila that, it should not be difficult to choose one fancy dress from her closet. Her family already gives Naila ten luxurious clothes that Naila can easily choose. Nasim subtly says that Naila should not make troubles in the house. 
Negative Impacts of Forced Marriage in Aisha Saeed's Novel Written In The Stars, Kahfiatika, M. Manugeren

Nasim regards that the sarcastic comments to Naila is to remind her that she should always behave as told:

..."I remember when you first arrived, everyday a new outfit and a new gold set. A proper bride."Feiza fidgets in her chair and casts a glance in my direction.

..."She just has a good attitude," Saba says. .but

have you ever seen her complain? She has a good temperament. Not everyone is gifted with that." (Saeed, 2000: 165).

The sarcastic comments given by Nasim are not only to compare Naila and Feiza's behavior, but also to remind Feiza not to behave like Naila. Nasim praises the good etiquette of Feiza; she always obeys and never complains. Simultaneously, Nasim has warned Feiza to continue like that and Naila needs to behave like Feiza.

\subsection{Loss of Social Relationship}

It is already known that a person's social environment can affect their health, with those who are socially isolated-that is, lonely suffering from higher mortality than people who are not. Feelings of social isolation are linked to alterations in the activity of genes that drive inflammation.

One of the negative effects of forced marriage is the loss or breakdown of social relationship that has been established, whether it is friendship or the relationship between the child and parents. Termination of this relationship can occur from one party, it can be the child who breaks the relationship or vice versa the parents who break the relationship or even both parties decide to break the relationship. It is possible for the child to disconnect because the anger of the Forced Marriage they experience. Parents may decide to cut ties with their children so that the child does not get support or a reason to run away from her forced marriage. The following quotations proves the loss of social relationship that happens in the novel:

...Khala Simki's eyes light up as she hugs me. She seems not to notice my hands hanging limp at my sides. My mother approaches me.

reaches out to embrace me, but no-I can't. I take a step back and look away (Saeed, 2000: 189).

When Khala Simki hugs Naila, Naila does not return her hug likewise, when Naila's mother approaches and wants to hug Naila, Naila backs down and refuses to see her mother. This is because of her anger towards her family because of forced marriage that happens to her. Naila's family has lost their harmonious relationship with Naila.

The quotation describes the loss of a relationship between father and daughter. They have lost the relationship not only because of forced marriage, but also because of her father's decision to comeback to US without telling Naila. The quotation below, shows that Naila feels betrayed by her father:

My brother and father are gone. I try to process this. They've resumed their life, as though I was never a part of it. I want to feel something, but no emotion rises to the surface. I feel outside of myself, observing events in a parallel universe I no longer inhabit (Saeed, 2000: 190). 
It is portrayed that Naila is shocked by the actions of her father and brother who return to US without telling her. Naila feels betrayed by her father. From that statement, It is seen that Naila feels disappointed because her father leaves her. Naila and her father has lost the relationship between father and daughter. The pain that Naila feels cannot even be felt anymore, Naila cannot feels any emotions anymore. Even the warmth of the family that is happening around her at home does not mean anything to her.

Then, the next quotation is other evidence that shows the loss of social relations between Naila and her boyfriend and friends in US. Here we can see how Naila is looking for her phone hidden by her father. She wants to contact her friends and boyfriend in the US but Naila must know that all is gone:

"It's gone." I freeze. Selma is at the door, watching me. "What's gone?"

"The phone. Your dad, he destroyed it." "You're sure?" "Yes," she says softly. "I saw the broken pieces in the trash can after you got married" (Saeed, 2000: 196).

The quotation shows how Naila's father breaks Naila's relationship with her boyfriend and friends by destroying her phone right after her wedding. It can be seen how Naila's father breaks all relations that Naila has in US. All hope of Naila has gone.

\section{Conclusion}

After analyzing the negative impacts of forced marriage in Aisha Saeed's novel Written in the Stars, the writer comes to conclusions that the implementation of forced marriage is still common among young women in rural villages in Pakistan. The implementation of forced marriage will only bring negative impacts to one or both parties. Physical violence often occurs in forced marriages, it can be from her husband or in-laws or other family members or even the bride own family and its common things to happen for them. In forced marriages, brides often receive mental pressure due to verbal abuse they receive from their husband's family members. And also forced marriage causes a reduction or loss of the relationship between the bride and her family. Forced marriage should never happen in the first place. Overall there are two forms of negative impacts in the results of the study, violence and loss of social relationship. Violence is again divided into two forms, physical violence and verbal abuse.

\section{References}

Bredal.A. (2011). Between Power and Powerlessness. Vol. 1, No. 4. Oslo: Institute for Social Research.http://www.socialresearch.no/ content/download/

31823/630521/file/R_2011_4web.pdf (12 March 2019)

Cresswell, W. J. (2013). Mixed Method Research. Nebraska: University Press.

Creswell, J. W. (1994). Qualitative inquiry and research design: Choosing among

five traditions (3rd ed.). Thousand Oaks, CA: Sage.

Flannery, D. J., Vazsonyi, A.T. \& Waldman, I.D. (Eds.) (2015). The Cambridge handbook of violent behavior and aggression. Cambridge: Cambridge University

Herbert, Martin. (1993). Planning a Research Project. London: Cassel.

Holly, Kellie. (2016). What is Verbal Abuse? Healthy Place. https:// www.healthyplace.com/abuse/verbal-abuse/what-is-verbal-abuse (23 March 2019)

Holt-Lunstad, Julianne. (2018). Why Social Relationships Are Important for Physical Health: A Systems Approach to Understanding and Modifying Risk and 
Negative Impacts of Forced Marriage in Aisha Saeed's Novel Written In The Stars, Kahfiatika, M. Manugeren

Protection. Annual Review of Psychology Vol. 69:437-458. Retrieved from https://doi.org/10.1146/annurev-psych-122216-011902 (22 March 2019)

Kefalas, Maria J. et.al. (2011). Marriage is More than being Together: The Meaning of Marriage for Young Adults.ResearchGate.Vol. 32, No. 7. Retrieved from https://www.researchgate.net/publication/254114959

Marriage_Is_More_Than_Being_TogetherThe_Meaning_of_Marriage_for_You ng_Adults (11 March 2019)

Millbank, Jenni. (2011). Forced Marriage and the Exoticization of Gendered Harms in United States Asylum Law.Colombia Journal of Gender and Law. Vol. 19, No. 3.https://papers.ssrn.com/sol3/papers .cfm? abstract_id=1757283 (1 March 2019)

Psaltis, Charis, et.al. (2015). Social Relations in Human and Societal Development.ResearchGate. https://www.researchgate.net /publication /267154718_SocialRelations_in_Human_and Societal_Development (30 March 2019)

Rangkuti, Rahmadsyah, et.al. 2019. Hate Speech Acts: A Case in Batu Bara. Language Literacy: Journal of Linguistics, Literature and Language Teaching. Vol. 3, No. 2. https://jurnal.uisu.ac.id/index.php/languageliteracy/article/view/1998/pdf (December 2019)

Sabbe, Alexia. et.al. (2014).Forced Marriage: An Analysis of Legislation and Political Measures in Europe. Springer. http://icrh.org/sites/default/files /forced\%20marriages\%20paper.pdf on (3 March 2019)

Schlack, R. J. Rudelet. al. (2013). Physcial and Psychological Violence Perpetration and Violent Victimization in the German Adult Population. Berlin: Springer-Verlag Berlin

Heidelberg. http://www.Violenciaintrafamiliar.es/download/Informe\%20de\%20victimizaci\% C3\%B3n\%20en\%20Alemania\%20Encuesta\%20de\%20salud\%20DEGS1.pdf (20 March 2019) 